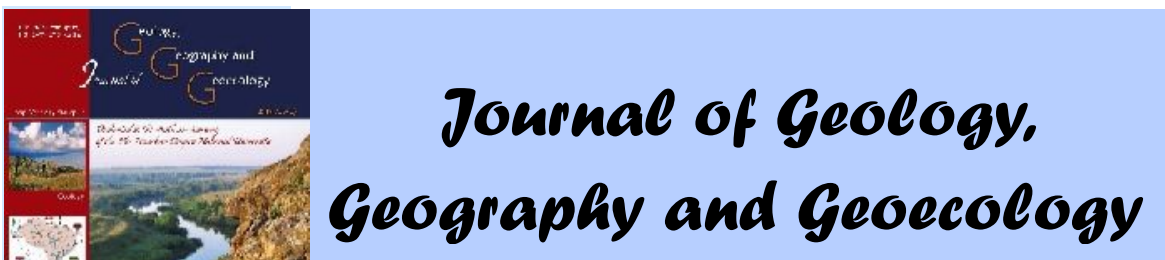

Journal home page: geology-dnu-dp.ua
Journ.Geol.Geograph.

Geoecology,

27(2), 232-243

doi: $10.15421 / 111848$

V. . Khilchevskyi, M.R. Zabokrytska, N.P. Sherstyuk

Journ.Geol.Geograph.Geoecology, 27(2), 232-243

\title{
Hydrography and hydrochemistry of the transboundary river Western Bug on the territory of Ukraine
}

\author{
V. . Khilchevskyi ${ }^{1}$, M.R. Zabokrytska ${ }^{2}$, N.P. Sherstyuk ${ }^{3}$ \\ ${ }^{I}$ Taras Shevchenko National University of Kyiv, Kyiv, Ukraine \\ e-mail: hilchevskiy@ukr.net \\ ${ }^{2}$ LesyaUkrainka Eastern European National University, Lutsk, Ukraine \\ e-mail:mirazabor@ukr.net \\ ${ }^{3}$ Oles GoncharDnipro National University, Dnipro, Ukraine \\ e-mail:sherstuknp@gmail.com
}

Received 27.05.2018;

Received in revised form 05.07.2018;

Accepted 23.07.2018

Abstract.The analysis of the hydrographic network of the Western Bug basin on the territory of Ukraine. This basin is estimated according to the requirements of the EU Water Framework Directive and has 2,044 rivers. Classification of the rivers of the Western Bug by area of drainage basins has shown the following results: in this basin within Ukraine there is one very big river, in fact this is the Western Bug itself. There are also three large rivers - Poltva, Rata and Luha. There are also 30 medium and 2,010 small rivers (among which 1,966 rivers have a length of less than $10 \mathrm{~km}$ ). Theleading role of natural factors in the formation of the hydrocarbonate-calcium ion composition of the river waters of the Western Bug basin is determined. The content of the main ions and the salinity of the river waters are distinguished by a sufficiently clear seasonal character: a decrease in the spring flood and an increase in the low water level (mineralization of the water of the Western Bug - 497-573 mg/l). Mineralization of the Poltva River (the left tributary of the Western Bug), located in the same natural conditions, is significantly different: in the area of the city of Lviv (the upper reaches of the Poltva River), it reaches 784-871 mg/l, and at the estuary of the river (Busk city, at the confluence of the Western Bug) is slightly reduced - 613-670 $\mathrm{mg} / \mathrm{l}$, while in the chemical type of water, sulfates and chlorides appear. This situation is explained by the discharge of sewage from the city of Lviv into the Poltva River. In the regime of nutrients, microelements, and also specific pollutants in the water of the West Bug, no general regularities in their seasonal variations were found, which is associated with the significant idiosyncratic character of the influence of anthropogenic factors on the formation of their concentrations. We estimated the balance of substances, both natural and anthropogenic, which are carried out with the waters of the Western Bug from the territory of Ukraine (93\%), as well as from the territory of Poland (7\%) to the border with Belarus. The comparative methodological approach allowed us to make a quantitative assessment of the significant influence of the Poltva River on the formation of the chemical composition of the water of the Western Bug, especially in its upper part. The share of Poltva's water flow when it flows into the Western Bug is 58\% of its water flow. At the same time, the share of the total ion flow is higher $-66 \%$. The share of the discharge of individual principal ions reaches: $76 \%\left(\mathrm{Cl}^{-}\right)$, $87 \%\left(\mathrm{Mg}^{2+}\right)$ and $98 \%\left(\mathrm{SO}_{4}^{2-}\right)$. For nitrogen, this figure is $68 \%$, for phosphates - up to $80 \%$.

Key words:transboundary river, hydrography, chemical composition of water, hydrochemical regime, ionic stream, waste of chemical substances

\section{ідрогр фія і гідрохімія тр нскордонної річки хідний}

ільчевський . . ${ }^{1}$, бокрицк . . ${ }^{2}, \quad$ ерстюк . . ${ }^{3}$

иївський н иіон льний університет імені $\quad$ с $\quad$ евченк, иїв, кр їн, e-mail: hilchevskiy@ukr.net 2 хідноєвропейський н ціон льний університет імені есі кр їнки, уцьк, кр їн, e-mail: mirazabor@ukr.net 3 ніпровський н ціон льний університет імені леся онч, ніпро, кр їн, e-mail: sherstuknp@gmail.com

нот ція. ведено х р ктеристику гідрогр фічних особливостей тр нскордонного б сейну хідного угу н території кр їни, гідрогр фічн мереж якого, оцінен з вимог ми , н лічує 2044 річки. ля гідрохімічних досліджень було обр но 14 створів. інер ліз ція води р. хідний уг ст новить 497-573 мг/л. інер ліз ція води р. олтв , лівої притоки хідного угу, що зн ходиться в тих же природних умов х, істотно відрізняється. к, в р йоні м. ьвов (верхів'я річки олтв ) вон сяг є 784-871 мг/л, в гирлі річки дещо знижується - 613-670 мг/л. я ситу ція пояснюється скид нням стічних вод м. ьвов в річку олтв . ослідження гідрохімічного режиму р. хідний уг т іiі приток 3 головними іон ми 
виявили чітку з лежність від гідрологічного режиму. е пояснюється впливом зміни ролі різних видів живлення річки протягом року. ередньорічний іонний стік хідного угу з території кр їни ст новить 793,5 тис. т бо 78,3 т/км²; 3 території кр їни т ольщі - 857,0 тис. т. ким чином, н цій ділянці річки $93 \%$ іонного стоку виноситься 3 території кр їни і $7 \%$ - 3 території ольщі. стк водного стоку р. олтв при її вп дінні в хідний уг ст новить $58 \%$ його водного стоку. той же ч с, ч стк іонного стоку р. олтв досяг є $66 \%$. ля з г льного зоту цей пок зник збільшується до $68 \%$, для фосф тів - до $80 \%$.

лючові слов : тр нскордонн річк, гідрогр фія, хімічний скл д води, гідрохімічний режим, іонний стік, стік хімічних речовин

Introduction.According to the hydrographic zoning of Ukraine, 9 river basin districts have been identified on its territory, one of which is the area of the Vistula basin, from which the river flow is directed to the Baltic Sea (about $2 \%$ of the territory of Ukraine). The area of the Vistula basin in the Ukrainian territory consists of two sub-basins: The Western Bug and the River San (Vodnyikodeks Ukrainy, 1995; Khilchevskyi, Hrebin, 2017). The basin of the Western Bug is located on the territory of three countries - Ukraine, Poland and Belarus. For $47 \%$ of its length $(363 \mathrm{~km})$, the river is transboundary - the state border of Poland and Ukraine, as well as Poland and Belarus, cross the river (Zabokrytska et al., 2006).

The Western Bug River lies in the sphere of interests of many researchers, primarily as a transboundary basin, where it is necessary to unite the efforts of the representatives of Ukraine, Belarus and Poland with the participation of the European Union structures in addressing water management issues (Karpuk, 2015; Khilchevskyi et al., 2016; Tränckner J. et al., 2012; Hagemann N., et al., 2014). Considerable attention is paid to the issues of anthropogenic impact on water quality and the ecological situation in the Western Bug basin (Charakterystykawod, 1999; Bug River Valley, 2002; Tokarchuk, 2011; Ertel et al., 2012; Tatukh et al., 2012; Starodub et al., 2013; Dzham, Danilyuk, 2017).

General hydrographic characteristic. The Western Bug River (in Polish - Bug) is the left tributary of the river Narew, which flows into the river Vistula (the Baltic Sea basin). The total area of the West Bug basin is $39,420 \mathrm{~km}^{2}$, the length of the river is $772 \mathrm{~km}$. According to the West Bug Basin Management of Water Resources of the State Agency of Water Resources of Ukraine, the area of the Western Bug basin in Ukraine is $11,205 \mathrm{~km}^{2}$ (over $28 \%$ of the total area of the basin), the length of the river is $404 \mathrm{~km}$ (over $52 \%$ of the total length), of which $220 \mathrm{~km}$ - the section of the river along which the border of Ukraine and Poland passes (Zakhidno-Buzke, 2017; Khilchevskyi et al., 2016).

In Ukraine, there are the source and the upper course of the Western Bug (Fig. 1). The source of the river is located within the Main European Watershed, on the northern outskirts of the Volynian-Podolian Upland in the Koltovskaya Basin near the village. Verkhobuzh, Zolochiv district, Lviv region. Between the source and the town of Ustyluh in the Volyn Oblast, the river is submontane, flows at an elevation - accross a hilly, rugged terrain. Below the city of Ustyluh, the Western Bug flows along the western outskirts of the Polesia lowland in a wide valley and has a pattern of a typical plain river.

The Ukrainian part of the basin of the Western Bug lies within the two administrative regions of Ukraine - Lviv and Volyn. Geographically, on the south-west, it borders with a basin of the San river (Vistula basin), in the south - with the river basin of the Dniester, and with a river basin of the Pripyat in the east. In the west, the Ukrainian part of the Western Bug basin reaches the state border of Ukraine and Poland, in the north - to the state border of Ukraine and Belarus.

The hydrographic network of the Ukrainian part of the Western Bug basin has 2,044 rivers. In the Water Code of Ukraine, these rivers are divided according to catchment area into: large - over $50,000 \mathrm{~km}^{2}$; average - 2,000-50,000 $\mathrm{km}^{2}$; small less than 2,000 $\mathrm{km}^{2}$ (Vodnyikodeks Ukrainy, 1995). According to this classification, the Western Bug River is an average river, and all its tributaries are small rivers.

At the same time, the classification of rivers by catchment area according to the Water Framework Directive (WFD) of the European Union, which is also used in Ukraine as a standard for assessing the ecological state of surface water masses, differs significantly: very large rivers - over 10,000 $\mathrm{km}^{2}$; large $-1,0-10,000 \mathrm{~km}^{2}$; average $-100-1,000$ $\mathrm{km}^{2}$; small - 10-100 km² (Directive, 2000/60/EC).

The application of the EU WFD type classification in the Ukrainian part of the Western Bug Basin shows the following: there is one very large river within the basin in Ukraine, the Western Bug, and three large rivers - Poltva $\left(1,440 \mathrm{~km}^{2}, 60.0\right.$ $\mathrm{km})$, the Rata $\left(1,820 \mathrm{~km}^{2}, 76.0 \mathrm{~km}\right)$ and the Luha $\left(1,351 \mathrm{~km}^{2}, 89.1 \mathrm{~km}\right)$. 


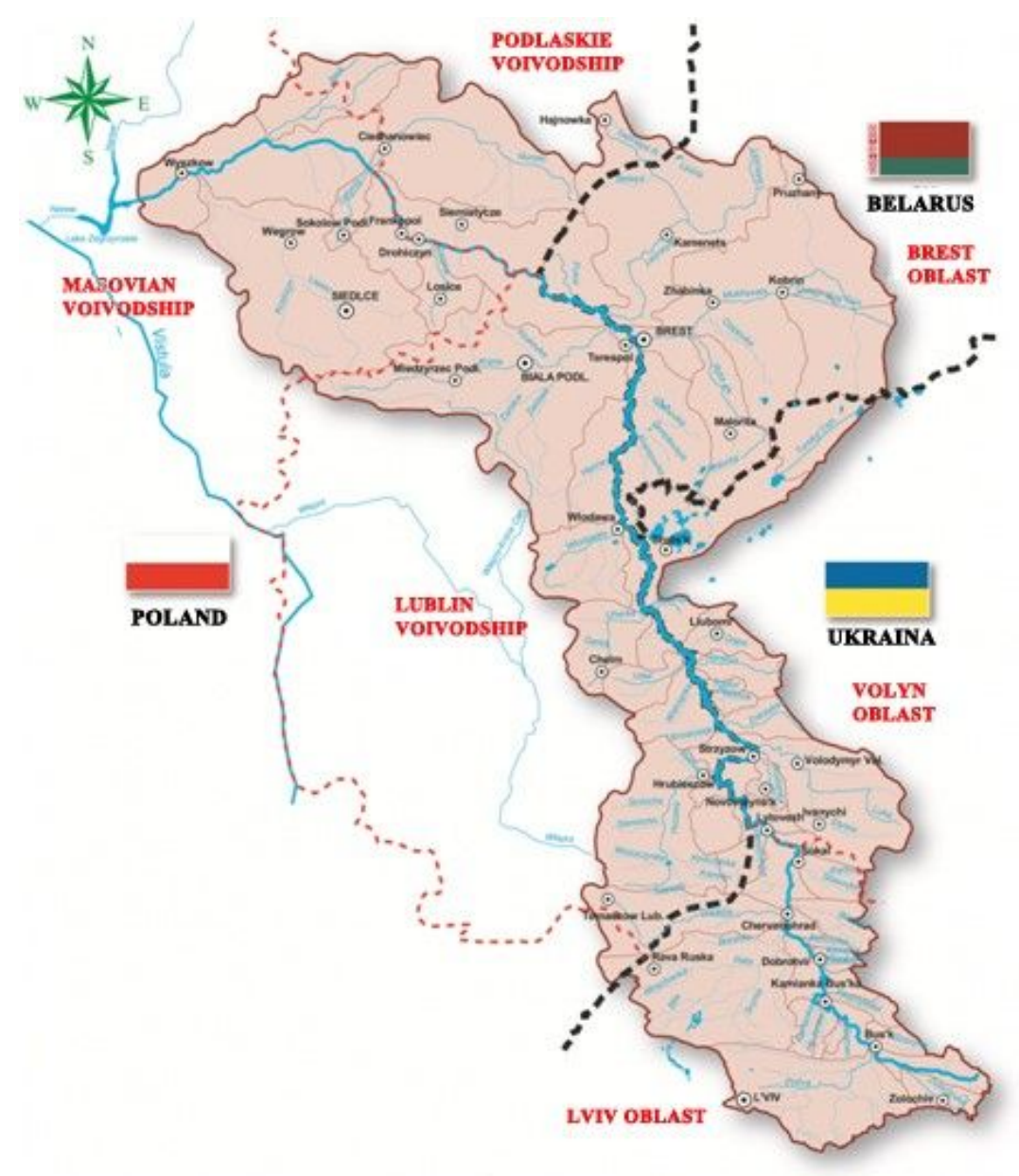

Fig. 1. Map of the basin of the Western Bug river on the territory of Ukraine, Poland and Belarus (Zakhidno-Buzke, 2017)

If the Poltva and Luha basins are completely located within Ukraine, the Rata originates in the PodkarpackieVoivodeship of Poland, a few kilometers from the Ukrainian-Polish border, respectively, and the upper part of the river basin with an area of about $50 \mathrm{~km}^{2}$ is located in the neighboring state.

Within the Ukrainian part of the Western Bug basin, according to the EU WFD classification, there are also 30 medium rivers (with a catchment area of 100-1,000 $\mathrm{km}^{2}$ ) and 2,010 small rivers (up to $100 \mathrm{~km}^{2}$ ). Among the small rivers, 44 watercourses have a length of more than $10 \mathrm{~km}$, and 1,966 small rivers have a length of less than $10 \mathrm{~km}$.

Factors of the formation of chemical composition of the river waters. A distinctive feature of the geological structure of the catchment area of the Western Bug in Ukraine is the occurrence of erosion of the Upper Cretaceous carbonate rocks above the local bases, which are represented by significantly fissured and karstic limestones and marls, the influence of which determines the formation of the salt composition of the river (Khilchevskyi, Kurylo, Sherstyuk, 2018).

The basin relief is characterized by incised, erosional forms of the Volynian-Podolian Upland relief, as well as flat and flat-hollow forms on the Polesia lowland. In addition, the karst forms of the relief are widespread on the areas where the carbonate rocks are bedded closely to the surface of.

The climate of the basin is moderate continental. The distribution of the annual amount of atmospheric precipitation within the catchment area of the Western Bug with a significant total wetting of the territory is uneven and exceeds the evaporation. Areas with the highest precipitation values are in the upper reaches of the river (annual precipitation is $-800 \mathrm{~mm}$ ). With a decrease in the al-titude of the catchment area, the amount of precipitation decreases to $650 \mathrm{~mm}$.

Soils in the basin are mainly podzolizedchernozems, in the floodplain of the river - soddy, marshy, characterized by a light mechanical composition (light loamy, sandy loamy). In such soils, in the conditions of humid climate, a washing regime is formed, which does not contribute to the increase in the mineralization of water.

The hydrogeological conditions of the territory of the Western Bug basin are determined by its belonging to the Polish-Lithuanian artesian basin, the northern and central parts of which are characterized by significant groundwater reserves. The conditions for the formation of groundwater in the basin are generally favorable. Due to the structural features of the water, Quaternary and pre- 
Quaternary sediments have a direction of movement from south to north.

Water consumption and water disposal.The formation of hydrochemical characteristics is significantly influenced by economic activity (ploughing, land improvement, water consumption, wastewater discharges, etc). The most significant factors which affect this basin are water consumption and water disposal.

In the 2000s, there was observed a decrease in the water consumption in the basin of the Western Bug, as in Ukraine in general. The basic structure of water consumption during that period in the basin of the Western Bug by different spheres remained practically unchanged. According to the State Agency for Water Resources of Ukraine, in 2015, it was as follows: $54 \%$ - housing and municipal services; $15 \%$ - the industry; $30 \%$ - agriculture; $1 \%$ - other needs.

The largest water consumption in the basin was recorded in $1992-135$ million $\mathrm{m}^{3}$; in 2001 115 million $\mathrm{m}^{3}$ (Zabokrytska, Khilchevskyi, Manchenko, 2006). In 2015, according to the State Agency for Water Resources of Ukraine in the basin of the Western Bug, 90 million $\mathrm{m}^{3}$ of water were collected, of which $20 \%$ were the surface waters, $80 \%$ were groundwater. Accordingly, the maximum discharge of wastewater was also recorded in $1992-245$ million $\mathrm{m}^{3} ; 2001-195$ million $\mathrm{m}^{3} ; 2015-180$ million $\mathrm{m}^{3}$. It should be mentioned that the indicator of wastewater discharge in the Ukrainian part of the Western Bug basin is twice as high as the same parameter of the water intakes. This is because Lviv consumes water both from the basin of the Western Bug and from the Dniester Basin, and all wastewater is discharged into the river system of the Western Bug.

The largest source of wastewater discharges in the West Bug basin is the city of Lviv with a popu-lation of 728 thousand people as of January 1, 2017. The annual volumes of sewage of this city, which enter the Western Bug through the river Poltva which flows into it near the town of Busk, make over $80 \%$ of the total volume of sewage that is discharged in the Ukrainian part of the basin.

Other anthropogenic factors. A number of mines of the Lviv-Volynhian Coal Basin function in this territory - Chervonohrad (population of 67 . 2 thousand people), Novovolynsk (52.6 thousand people); $40 \%$ of the surface of the basin was previously drained, $80-90 \%$ of the drainage water receipts were straightened; The plowed area is almost $42 \%$.

Hydrological conditions. In the upper reach, the valley of the Western Bug has terraces (width $1-3 \mathrm{~km}$ ), the floodplain of the river is swampy, and there are oxbow lakes. The streambed is si- nuous (width up to 8-15 m), and channeled in some areas. The drainage density in the territory of the Lviv Oblast is $0.35 \mathrm{~km} / \mathrm{km}^{2}$. In the middle of the river, the width of the valley reaches $3-4 \mathrm{~km}$, the floodplain is manifested insignificantly. The width of the channel reaches $40 \mathrm{~m}$. Towards the lower part of the stream, the Western Bug narrows to 1.0$1.5 \mathrm{~km}$, usually, the streambed width is $50-75 \mathrm{~m}$, and in some areas reaches $100 \mathrm{~m}$. The stream gradient equals $0.3 \mathrm{~m} / \mathrm{km}$. The speed of the current in LvivOblast is $0.3-0.6 \mathrm{~m} / \mathrm{s}$, and decreases to $0.1-0.2$ $\mathrm{m} / \mathrm{s}$ in the Polesia part, which is related to a slight decline of the surface. In the basin of the Western Bug (within the Volyn Oblast) there are over 80 lakes with a total area of $92 \mathrm{~km}^{2}$, and the drainage density is $0.22-0.35 \mathrm{~km} / \mathrm{km}^{2}$.

For the hydrological regime of the Western Bug, a distinctive feature is significant spring flood and low summer-autumn and winter drought flows which are characterized by low water content and considerable duration. Different degrees of karst development and swampiness in some areas of the basin determine the natural regulation of water runoff, especially during the spring flood. Therefore, in the territories with karst and marshes in the same region, the average multi-year spring runoff differs in 1.5-2.0 times. Within the Lower Polesia, the influence of karst on the formation of spring runoff characteristics is the least. Therefore, the largest layer of spring flood runoff is typical for the rivers of this region (the Rata, the Zheldets and the Solokiya) - $129-158 \mathrm{~mm}$ and exceeds their value for the rivers of the Podolian Upland (the Poltva, the Holoivka, the Kamenka) - 93-115 mm.

The drought flow runoff from the rivers of the Western Bug basin occurs due to ground waters of marl and chalk (karst) and limestone strata. With its water reserves, this water-bearing horizon provides a long-term and sustainable supply to the basin's rivers during periods of absence of surface runoff. Dur-ing summer-autumn drought flow, the values of the runoff layer are higher (104-122 mm) compared to winter drought flow.

The following average annual water discharges in the Western Bug by the drains: Sasivvillage (the upper reach of the river) $-1.12 \mathrm{~m}^{3} / \mathrm{s}$; Sokal - $29.5 \mathrm{~m}^{3} / \mathrm{s}$; "Border-3" - $52.3 \mathrm{~m}^{3} / \mathrm{s}$ (conditional drain at the border of Ukraine, Poland and Belarus, the closing drain in the Ukrainian part of the basin) (Zabokrytska, Khilchevskyi, Manchenko, 2006).

For the Western Bug, there is a significant intra-annual variability in sediment runoff. During the spring flood tide, the river carries $50 \%$ of the annual amount of suspended matter, and in the summer-autumn and winter drought flow, 30 and $20 \%$, respectively. 
Hydrochemical regime. To characterize and evaluate the hydrochemical regime of the rivers of the Western Bug Basin, 14 drains were selected: 7 on the Western Bug (above and below or within the boundaries of the cities of Busk, Kamianka-Buzka, Sokal) and 7 on the tributaries (the Poltva River Lviv and Busk, the Rata River -Mezhirichia village; the Solokiya River - Chervonograd; the Luha river - the city of Vladymyr-Volynskyi). We analyzed a series of examinationss of the chemical composition of water for the period of 1971-2015, obtained by the Hydrometeorological Service of Ukraine (which since 2012 is in the system of the State Service of Ukraine for Emergencies). The initial long-term information for each monitored drains was grouped by the main seasons: spring high water, summer-autumn and winter drought flow. This allowed us to determine genetically homogeneous pieces of information that characterize the periods with the predominance of certain processes of formation of the chemical composition of the river waters under the influence of seasonal changes.

The article describes the chemical composition of the water of the Western Bug River as an average value for 7 drains. On the river Luha, the averaged values were calculated for 3 drains. The Poltva River was characterized by two drains: in Lviv (the upper reach of the river) and Busk (the mouth of the river) for there are significant differences between them in the chemical composition of the water.

Study of the hydrochemical regime of the Western Bug and its tributaries by the main ions revealed a clear seasonality, which is explained by the influence of the change of the role of different types of support throughout the year.

The lowest values of the total mineralization of the Western Bug water were observed during the spring flood $(497 \mathrm{mg} / \mathrm{l})$; In the periods of lowwater, the amount of mineralization ranged 518 $\mathrm{mg} / \mathrm{l}$ (summer-autumn low-level) to $573 \mathrm{mg} / \mathrm{l}$ (winter low-water level). A similar pattern was also observed for the seasonal course of the concentrations of individual major ions in the water of the Western Bug (Table 1).

The values of the concentrations of the main ions and the mineralization in the water of tributaries in different seasons are close to these characteristics in the water of the Western Bug. An exception is the relatively high mineralization of the river Poltva, which in the drain in Lviv reaches 784-871 $\mathrm{mg} / \mathrm{l}$, reducing in the mouth of the river (in the city of Busk) to $613-670 \mathrm{mg} / \mathrm{l}$.

The ionic composition of theriver waters of the basin is genetically associated with poorly soluble carbonate rocks that lie on its drainage basin.

Table 1. Average Seasonal Concentrations of Main Ions and Water Salinity Value.The Western Bug and its tributaries, mg/l

\begin{tabular}{|c|c|c|c|c|c|c|c|c|}
\hline $\begin{array}{l}\text { TheMainriver } \\
\text { /tributaries }\end{array}$ & $\mathrm{HCO}_{3}^{-}$ & $\mathrm{SO}_{4}{ }^{2-}$ & $\mathrm{Cl}^{-}$ & $\mathrm{Ca}^{2+}$ & $\mathrm{Mg}^{2+}$ & $\mathrm{Na}^{+}$ & $\mathbf{K}^{+}$ & $\begin{array}{l}\text { Total minera- } \\
\text { lization }\end{array}$ \\
\hline \multicolumn{9}{|c|}{ Spring Flood } \\
\hline $\begin{array}{l}\text { The Western Bug } \\
\text { River }\end{array}$ & 275 & 50 & 50 & 88 & 13 & 20 & 3.0 & 497 \\
\hline Poltva - Lviv & 330 & 120 & 131 & 140 & 18 & 40 & 5.0 & 784 \\
\hline Poltva - Buskcity & 302 & 102 & 74.8 & 107 & 24.1 & 25.7 & 3.7 & 640 \\
\hline Rata & 231 & 37.9 & 33.6 & 82.2 & 9.5 & 17.7 & 2.5 & 414 \\
\hline Solokiya & 248 & 31.1 & 34.6 & 85.7 & 10.5 & 9.9 & 1.4 & 421 \\
\hline Luha & 298 & 30.1 & 20.1 & 83.2 & 10.9 & 37.6 & 5.5 & 487 \\
\hline \multicolumn{9}{|c|}{ Summer-autumn low-water period } \\
\hline $\begin{array}{l}\text { The Western Bug } \\
\text { River }\end{array}$ & 288 & 54 & 50 & 92 & 15 & 30 & 4 & 518 \\
\hline Poltva - Lviv & 358 & 104 & 110 & 124 & 15 & 80 & 11 & 801 \\
\hline Poltva - Buskcity & 304 & 75.8 & 64.6 & 110 & 18.9 & 32.4 & 4.6 & 613 \\
\hline Rata & 248 & 37.8 & 32 & 84.1 & 10.1 & 18.1 & 2.5 & 433 \\
\hline Solokiya & 256 & 43.2 & 40.0 & 88.1 & 10.0 & 15.2 & 2.1 & 455 \\
\hline Luha & 306 & 29.3 & 18.1 & 81.9 & 11.4 & 32.5 & 4.8 & 484 \\
\hline \multicolumn{9}{|c|}{ Winter low-water period } \\
\hline $\begin{array}{l}\text { The Western Bug } \\
\text { River }\end{array}$ & 303 & 64 & 57 & 104 & 17 & 35 & 5 & 573 \\
\hline Poltva - Lviv & 347 & 187 & 137 & 134 & 23 & 38 & 5.0 & 871 \\
\hline Poltva - Buskcity & 331 & 100 & 92 & 107 & 23.2 & 14,3 & 2.1 & 670 \\
\hline Rata & 277 & 32 & 33.3 & 88.8 & 9.3 & 30.7 & 4.3 & 476 \\
\hline Solokiya & 265 & 33.3 & 37.2 & 94.6 & 8.8 & 21.1 & 3.0 & 463 \\
\hline Luha & 322 & 29.8 & 17.1 & 84.2 & 14.1 & 34.1 & 4.7 & 508 \\
\hline
\end{tabular}


Accordingly, in all seasons of the year, $\mathrm{HCO}_{3}{ }^{-}$and $\mathrm{Ca}^{2+}$ ions predominate in the water. The waters of the Western Bug basin belong to the hydrocarbonate class of the II type calcium group -

The contribution of individual ions is as follows: for anions: $\mathrm{HCO}_{3}^{-}(63-64 \%$-eq. $)>\mathrm{Cl}^{-}(21-$ $22 \%$-eq.) $>\mathrm{SO}_{4}{ }^{2-}\left(15-16 \%\right.$-eq); for cations: $\mathrm{Ca}^{2+}$ $(63-66 \%-$ eq $)>\mathrm{Na}^{+}+\mathrm{K}^{+}(16-21 \%-$ eq $)>\mathrm{Mg}^{2+}$ (15-18\% -eq).

The performed correlation analysis of the series of mean annual concentrations of the main ions and the mineralization values with water flow the Western Bug (Kamianka-Buzka) for the period 1971-2015 revealed the presence of biological feedback between the content of all the main ions and the mineralization of the water, on the one hand, and discharge of water on the other. The close relationship was characterized by the correlation coefficient $r=0.73$. This indicates the effect of the hydrolicity(ratio of the average discharge over the entire reference period) on the content of the main ions in the water of the river in a multi-year aspect.

For the studied period (1971-2015), periods with average water content and also low-water and high-water periods were noticeable. A comparative analysis of the values of the water indicators of the Western Bug in 7 drains located directly on the river revealed that the maximum concentrations occurred in low-water periods, and the minimum values in high-water periods. However, the local influence of the settlements on the chemical composition of the water of the Western Bug was also significant, manifesting through increases in the concentrations of certain main ions $\left(\mathrm{SO}_{4}^{2-}, \mathrm{Cl}^{-}\right)$and the mineralization of water in insignificant sections of the river located below the cities. Consequently, the results of studies of the hydrochemical regime of the Western Bug and its tributaries, both in the intra-annual and long-term aspects, attested to the determining role of natural factors in the formation of the contents of the main ions. The exception was the Poltva, for which, as it was mentioned above, the significant anthropogenic influence of Lviv is characteristic.

Among the studied biogenic substances, a clear seasonal distribution of concentrations was found only for nitrogen of nitrate and silicon (Table 2).

The lowest concentrations of $\mathrm{N}-\mathrm{NO}_{3}^{-}(0.39$ $\mathrm{mg} / \mathrm{l}$ ) were observed inthe summer during the vegetation period, when the nitrogen dissolved in water was intensively consumed by hydrobionts. During winter low-water, $\mathrm{N}-\mathrm{NO}_{3}^{-}$values increased $(0.49 \mathrm{mg} / \mathrm{l})$, which is related to the destruction of organic substances and the transition of nitrogen from organic forms to mineral forms following minimal bioaccumulation of nitrates. During the spring flood, the nitrogen concentrations of nitrate nitrogen were reduced due to dilution.

But for the concentrations of biogenic matter (see Table 2), microelements and specific pollutants (Tables 3 and 4), no clear common pattern in their seasonal fluctuations were found, which is related to the significant discreteness of the influence of anthropogenic factors on the formation of their concentrations.

Table 2. Average Seasonal Concentrations of biogenic matter in the Western Bug and its tributaries, mg/l

\begin{tabular}{|c|c|c|c|c|c|c|c|}
\hline $\begin{array}{l}\text { The Main river } \\
\text { /tributaries }\end{array}$ & $\mathrm{NH}_{4}{ }^{+}$ & $\mathrm{NO}_{2}^{-}$ & $\mathrm{NO}_{3}^{-}$ & $\mathbf{N}_{\text {total }}$ & $\min$. & total & Si \\
\hline \multicolumn{8}{|c|}{ SpringFlood } \\
\hline TheWesternBugRiver & 3.26 & 0.10 & 0.46 & 3.83 & 0.16 & 0.32 & 3.7 \\
\hline Poltva - Lviv & 14.8 & 0.15 & 0.45 & 15.4 & 1.17 & 1.80 & 7.2 \\
\hline Poltva - Buskcity & 6.7 & 0.12 & 0.43 & 7.25 & 0.44 & 0.83 & 4.8 \\
\hline Rata & 1.1 & 0.05 & 0.53 & 1.68 & 0.04 & 0.08 & 3.7 \\
\hline Solokiya & 1.8 & 0.11 & 0.36 & 2.29 & 0.06 & 0.12 & 4.1 \\
\hline Luha & 1.3 & 0.04 & 0.35 & 1.70 & 0.04 & 0.11 & 3.4 \\
\hline \multicolumn{8}{|c|}{ Summer-autumn low-water period } \\
\hline The Western Bug River & 3.0 & 0.1 & 0.39 & 3.49 & 0.20 & 0.43 & 4.3 \\
\hline Poltva - Lviv & 9.8 & 0.15 & 0.47 & 10.4 & 0.90 & 1.69 & 5.9 \\
\hline Poltva - Buskcity & 6.7 & 0.11 & 0.42 & 7.2 & 0.49 & 0.81 & 5.1 \\
\hline Rata & 0.9 & 0.04 & 0.28 & 1.22 & 0.05 & 0.14 & 4.4 \\
\hline Solokiya & 2.0 & 0.05 & 0.32 & 2.37 & 0.07 & 0.20 & 4.1 \\
\hline Luha & 1.1 & 0.06 & 0.25 & 1.4 & 0.05 & 0.11 & 3.6 \\
\hline \multicolumn{8}{|c|}{ Winterlow-waterperiod } \\
\hline TheWesternBugRiver & 3.63 & 0.14 & 0.49 & 4.28 & 0.17 & 0.35 & 4.4 \\
\hline Poltva - Lviv & 10.6 & 0.17 & 1.97 & 11.6 & 1.54 & 0.87 & 6.0 \\
\hline Poltva-Buskcity & 7.8 & 0.18 & 0.52 & 8.5 & 0.32 & 0.54 & 8.0 \\
\hline Rata & 1.18 & 0.07 & 0.54 & 1.79 & 0.05 & 0.12 & 4.2 \\
\hline Solokiya & 2.16 & 0.09 & 0.34 & 2.6 & 0.09 & 0.17 & 4.6 \\
\hline Luha & 1.3 & 0.16 & 0.50 & 2.1 & 0.09 & 0.31 & 4.3 \\
\hline
\end{tabular}


Table 3.Average seasonal concentrations of microelements in the water of the Western Bug and its tributaries

\begin{tabular}{|c|c|c|c|c|}
\hline $\begin{array}{l}\text { The Main river } \\
\text { /tributaries }\end{array}$ & Fe, mg/l & Cu, mcg/l & Zn, mcg/l & Mn, mcg/l \\
\hline \multicolumn{5}{|c|}{ SpringFlood } \\
\hline TheWesternBugRiver & 0.29 & 19.3 & 57.5 & 92.7 \\
\hline Poltva - Lviv & 0.48 & 60.3 & 160 & 161 \\
\hline Poltva - Buskcity & 0.13 & 84.6 & 129 & 150 \\
\hline Rata & 0.23 & 6.0 & 28.7 & 78 \\
\hline Solokiya & 0.19 & 7.4 & 6.1 & 77 \\
\hline Luha & 0.49 & 24.5 & 38.5 & 94 \\
\hline \multicolumn{5}{|c|}{ Summer-autumn low-water period } \\
\hline The Western BugRiver & 0.25 & 13.8 & 45.1 & 58.5 \\
\hline Poltva - Lviv & 1.33 & 24 & 43.5 & 166 \\
\hline Poltva - Buskcity & 0.61 & 16 & 64.8 & 158 \\
\hline Rata & 0.29 & 3.4 & 11.6 & 76 \\
\hline Solokiya & 0.29 & 8.0 & 11.3 & 78 \\
\hline Luha & 0.51 & 9.8 & 58.1 & 89.2 \\
\hline \multicolumn{5}{|c|}{ Winter low-water period } \\
\hline TheWesternBugRiver & 0.14 & 11.8 & 43.2 & 35.6 \\
\hline Poltva - Lviv & 0.47 & 6.3 & 2.4 & 158 \\
\hline Poltva - Buskcity & 0.62 & 62 & 93 & 144 \\
\hline Rata & 0.24 & 4.1 & 14.1 & 75 \\
\hline Solokiya & 0.22 & 8.4 & 16.5 & 73 \\
\hline Luha & 0.43 & 18 & 36.1 & 71.1 \\
\hline
\end{tabular}

Table 4.Average seasonal concentrations of specific pollutants in the water of the Western Bug and its tributaries, $\mathrm{mg} / \mathrm{l}$

\begin{tabular}{|c|c|c|c|}
\hline The Main river /tributaries & SPAR & Phenols & Petroleumproducts \\
\hline \multicolumn{4}{|c|}{ SpringFlood } \\
\hline TheWesternBugRiver & 0.07 & 0.005 & 0.15 \\
\hline Poltva - Lviv & 0.68 & 0.032 & 0.63 \\
\hline Poltva - Buskcity & 0.35 & 0.011 & 0.44 \\
\hline Rata & 0.05 & 0.002 & 0.75 \\
\hline Solokiya & 0.04 & 0.002 & 0.04 \\
\hline Luha & 0.05 & 0.004 & 0.24 \\
\hline \multicolumn{4}{|c|}{ Summer-autumn low-water period } \\
\hline The Western Bug River & 0.05 & 0.004 & 0.10 \\
\hline Poltva - Lviv & 0.01 & 0.033 & 0.27 \\
\hline Poltva - Buskcity & 0.10 & 0.003 & 0.13 \\
\hline Rata & 0.04 & 0.010 & 0.11 \\
\hline Solokiya & 0.03 & 0.001 & 0.06 \\
\hline Luha & 0.03 & 0.004 & 0.09 \\
\hline \multicolumn{4}{|c|}{ Winter low-water period } \\
\hline The Western Bug River & 0.07 & 0.003 & 0.09 \\
\hline Poltva - Lviv & 0.15 & 0.011 & 0.34 \\
\hline Poltva - Buskcity & 0.11 & 0.004 & 0.18 \\
\hline Rata & 0.08 & 0.001 & 0.06 \\
\hline Solokiya & 0.02 & 0.001 & 0.05 \\
\hline Luha & 0.04 & 0.001 & 0.09 \\
\hline
\end{tabular}


During all the seasons, significant occasional exceedances of TLV (threshold limit value) for biogenic matter, microelements and specific pollutants in water bodies for fishery use were determined in the water of the Poltva and in some cases in the Western Bug along the section from the city of Busk to the town of Kamianka-Buzka. This occurred due to the influence of water of the Poltva, which is polluted with these components. For some of these, these excesses remain at the averaged values ( $\mathrm{Fe}, \mathrm{Zn}, \mathrm{Mn}$ ).

Runoff of chemical elements. The study on the removal of dissolved chemicals with the waters of the Western Bug from the territory of Ukraine is particularly important and relevant in the light of the stricter requirements of the European Union (EU) regarding the transfer of pollutants from the territory of neighboring countries. As the previous studies indicated, the characteristics of the removal of chemicals with river waters can be an indicator of anthropogenic impact on the chemical composition of river waters (Zakrevskii et al., 1988; Khil'chevskii, Chebot'ko, 1994).

The ion runoff $\left(R_{i}\right)$ in a certain drain is calculated by the formula (Khilchevskyi, Osadchyi, Kurylo, 2012):

$R_{i}=W \quad C$, thousands of tons (for a season, for a year), where $\mathrm{W}$ - volume of runoff flow, thousand $\mathrm{m}^{3} ; \mathrm{C}$ -concentration of the ion (or the sum of the ions), $\mathrm{mg} / \mathrm{l}$.

The volume of water runoff $\mathrm{W}$ is calculated as follows:

$$
W=Q \quad t
$$

where $\mathrm{Q}$ - water discharge, $\mathrm{m}^{3} / \mathrm{s} ; \mathrm{t}$ - time (season, year).

No problems occur with average concentrations of chemical components in the water of the Western Bug. But how is it possible to determine water discharges by the closing drain in the Ukrainian part of the catchment area of the Western Bug, which in reality does not exist in the hydrological monitoring system?

For the calculations, a conditional hydrological drain "Border-3." was chosen on the Western Bug. Borders of three states cross here - Ukraine, Poland and Belarus, which is the closing drain in the Ukrainian part of the basin. For this conditional hydrological drain, we provided the characteristics of water discharge and water runoff volumes obtained through the runoff modules (Table 5). These data were used to calculate the runoff of chemicals.

Table 5. Average volume of water drain (W) of the Western Bug in the conventional drain "Border-3" (crossing of the borders of Ukraine, Poland and Belarus), the last in the Ukrainian part of the basin, million $\mathrm{m}^{3} / \mathrm{year}$

\begin{tabular}{|c|c|c|c|c|}
\hline Characteristic & Spring Flood & $\begin{array}{c}\text { Summer-autumnlow- } \\
\text { waterperiod }\end{array}$ & $\begin{array}{c}\text { Winterlow- } \\
\text { waterperiod }\end{array}$ & In a year \\
\hline $\begin{array}{c}\text { W - from the territory of } \\
\text { Ukraine }\end{array}$ & 918 & 382 & 229 & $1529 *$ \\
\hline $\begin{array}{c}\text { W - from the territory of } \\
\text { Ukraine and Poland }\end{array}$ & 990 & 413 & 248 & $1651^{* *}$ \\
\hline
\end{tabular}

Note: * - the average annual water discharge $(Q)$ in the conventional drain "Border-3", which is formed from the catchment area of the Western Bug in Ukraine, is $48.5 \mathrm{~m}^{3} / \mathrm{s}$; ** - in the territory of Ukraine and Poland $-52.3 \mathrm{~m}^{3} / \mathrm{s}$.

The average annual ion runoff of the Western Bug from the territory of Ukraine is 793.5 thousand tons $\left(78.3\right.$ tons $\left./ \mathrm{km}^{2}\right)$; from the territory of Ukraine and Poland $-857,0$ thousand tons (Table 6). As we can see, in this part of the river, $93 \%$ of ion runoff is taken from the territory of Ukraine and $7 \%$ from the territory of Poland (Fig. 2).

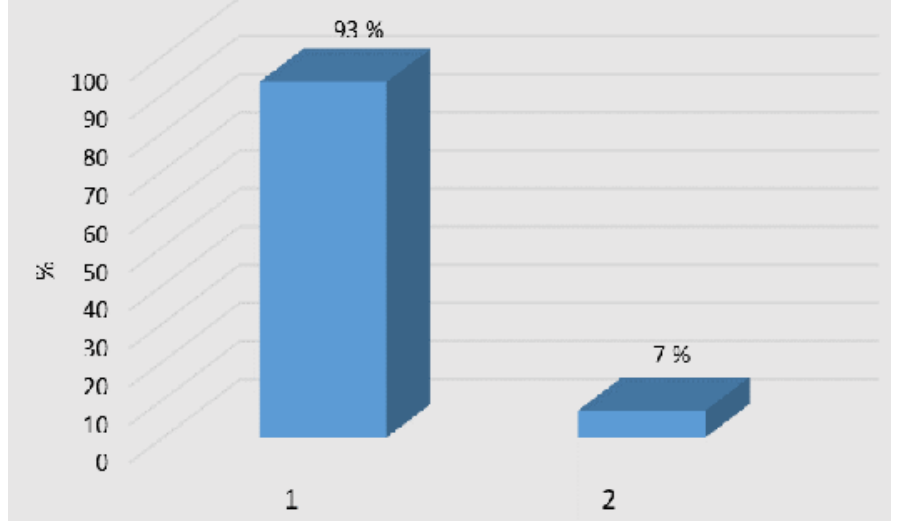

Fig. 2. Mean annual ion flow of the Western Bug from the territory of Ukraine (1) and from the territory of Poland (2) in the conventional drain "Border-3", the last in the Ukrainian part of the basin,\% 
Table 6. Average annual and average seasonal ion runoff of the Western Bug river from the territory of Ukraine (above the line thousand tons, below the line $-\mathrm{t} / \mathrm{km}^{2}$ )

\begin{tabular}{|c|c|c|c|c|c|c|c|c|}
\hline Season / Year & $\mathrm{HCO}_{3}^{-}$ & $\mathrm{SO}_{4}{ }^{2-}$ & $\mathrm{Cl}^{-}$ & $\mathrm{Ca}^{2+}$ & $\mathbf{M g}^{2+}$ & $\mathbf{N a}^{+}$ & $\mathbf{K}^{+}$ & $\begin{array}{l}\text { The sum } \\
\text { of ions }\end{array}$ \\
\hline Spring Flood & $\frac{250.6}{(23.2)}$ & $\frac{45.8}{(4.2)}$ & $\frac{47.4}{(4.4)}$ & $\frac{82.3}{(7.6)}$ & $\frac{11.6}{(1.0)}$ & $\frac{17.8}{(1.6)}$ & $\frac{2.5}{(0.2)}$ & $\frac{458}{(42.4)}$ \\
\hline $\begin{array}{l}\text { Summer- } \\
\text { autumnlow- } \\
\text { waterperiod }\end{array}$ & $\frac{108.1}{(10)}$ & $\frac{19.7}{1.8}$ & $\frac{20.4}{(1.9)}$ & $\frac{35.3}{(3.3)}$ & $\frac{5.9}{(0.5)}$ & $\frac{11.3}{(1.0)}$ & $\frac{1.6}{(0.1)}$ & $\frac{202.5}{(18.8)}$ \\
\hline $\begin{array}{l}\text { Winterlow- } \\
\text { waterperiod }\end{array}$ & $\frac{68.7}{(6.4)}$ & $\frac{13.7}{(1.3)}$ & $\frac{13.5}{(1.2)}$ & $\frac{24.0}{(2.2)}$ & $\frac{3.9}{(0.4)}$ & $\frac{8.0}{(0.7)}$ & $\frac{1.1}{(0.1)}$ & $\frac{133}{(12.3)}$ \\
\hline In a year & $\frac{427.4}{(39.6)}$ & $\frac{79.2}{(7.3)}$ & $\frac{81.3}{(7.5)}$ & $\frac{141.6}{(13.1)}$ & $\frac{21.4}{(1.9)}$ & $\frac{37.1}{(3.3)}$ & $\underline{5.2}$ & $\frac{793.5}{(73.5)}$ \\
\hline
\end{tabular}

In Table. 7 shows the data for the runoff of biogenic matter, Table. 8 - runoff of microelements with the waters of the Western Bug from the territory of Ukraine.

Table 7. Average annual and average seasonal runoff of biogenic matter with waters of the Western Bug from the territory of Ukraine (above the line - thousand tons, under the line $-\mathrm{t} / \mathrm{km}^{2}$ )

\begin{tabular}{|c|c|c|c|c|c|c|c|}
\hline Season / Year & $\mathrm{NH}_{4}{ }^{+}$ & $\mathrm{NO}_{2}^{-}$ & $\mathrm{NO}_{3}^{-}$ & $\mathbf{N}_{\text {total }}$ & $\min$. & total & $\mathbf{S i}$ \\
\hline Spring Flood & $\frac{3.0}{0.27}$ & $\frac{0.092}{0.008}$ & $\underline{0.4}$ & $\underline{3.5}$ & $\underline{0.1}$ & - & $\underline{3.4}$ \\
\hline $\begin{array}{l}\text { Summer-autumn } \\
\text { low-water period }\end{array}$ & $\frac{1.1}{0.1}$ & $\underline{0.037}$ & $\begin{array}{c}0.1 \\
0.009\end{array}$ & $\frac{1.3}{0.12}$ & $\underline{0.074}$ & - & $\frac{1.6}{0.15}$ \\
\hline $\begin{array}{l}\text { Winter low-water } \\
\text { period }\end{array}$ & $\frac{0.8}{0.074}$ & $\frac{0.031}{0.003}$ & $\frac{0.1}{0.009}$ & $\frac{0.9}{0.08}$ & $\frac{0.038}{0.003}$ & - & $\frac{1.0}{0.09}$ \\
\hline Over the year & $\frac{4.9}{0.45}$ & $\frac{0.16}{0.014}$ & $\frac{0.6}{0.055}$ & $\frac{5.7}{0.52}$ & $\frac{0.212}{0.019}$ & - & $\frac{6.0}{0.55}$ \\
\hline
\end{tabular}

Table 8. Average annual and average seasonal runoff of microelements with waters of the Western Bug from the territory of Ukraine (by Fe: above the line - thousand tons, under the line $-\mathrm{t} / \mathrm{km}^{2}$, by $\mathrm{Cu}, \mathrm{Zn}, \mathrm{Mn}$ : above the line - thousand $\mathrm{kg}$, under the line $-\mathrm{kg} / \mathrm{km}{ }^{2}$ )

\begin{tabular}{|c|c|c|c|c|}
\hline Season / Year & $\mathbf{F e}$ & $\mathrm{Cu}$ & $\mathbf{Z n}$ & Mn \\
\hline Spring Flood & $\frac{0.3}{0.28}$ & $\frac{17.7}{1.6}$ & $\frac{22.0}{2.0}$ & $\frac{85.0}{7.9}$ \\
\hline $\begin{array}{l}\text { Summer-autumn } \\
\text { low-water period }\end{array}$ & $\underline{0.095}$ & $\frac{5.3}{0.5}$ & $\frac{17.2}{1.6}$ & $\frac{22.3}{2.0}$ \\
\hline $\begin{array}{l}\text { Winter low-water } \\
\text { period }\end{array}$ & $\frac{0.032}{0.003}$ & $\frac{2.7}{0.3}$ & $\frac{9.9}{0.9}$ & $\frac{8.1}{0.7}$ \\
\hline Over the year & $\frac{0.42}{0.039}$ & $\frac{25.7}{2.4}$ & $\frac{49.1}{4.5}$ & $\frac{115.4}{10.6}$ \\
\hline
\end{tabular}

The runoff of different groups of chemical components that are carried out with the waters of the Western Bug is distributed by seasons as follows. The main ions: spring high water $-48-59 \%$; summer-autumn low-water period - 25-31\%; winter low-water $-16-22 \%$. Biogenic matter: spring high water - 47-67\%; summer-autumn low-water period - 17-35\%; winter low-water - 16-19\%. Heavy metals: spring high water $-45-74 \%$; sum- mer-autumn low - 19-35\%; winter low-water - 6$20 \%$.

Considering the specific nature of the chemical composition of the Poltva, we studied the contribution of this river to the formation of the main ion and biogenic matter runoff in the upper part of the Western Bug (right after the confluence of the PoltvaatKamianka-Buzka) and in the lower part of the Western Bug for Ukraine - on the border of Ukraine, Poland and Belarus (Table 9 and 10). The 
following methodical approach was used. The data calculated for the runoff of the mentioned chemical components, obtained for the mouth of the Poltva (Busk), were compared with the data for two drains on the Western Bug: 1) the Western Bug - Ka-
mianka-Buzka, below the confluence of Poltva (upper); 2) the Western Bug is the conventional drain "Border-3", the closing drain in the Ukrainian part of the basin (the lower one).

Table 9. Contribution of the Poltva to the water (W) and ionic runoff of the Western Bug, calculated for two drains: 1) the Western Bug - Kamianka-Buzka, below the confluence of Poltva (upper); 2) the Western Bug is the conventional drain "Border-3", the closing drain the Ukrainian part of the basin (lower), $\%$

\begin{tabular}{|l|c|c|c|c|c|c|c|c|}
\hline River, Drain & $\mathbf{W}$ & $\mathbf{H C O}_{\mathbf{3}}^{-}$ & $\mathbf{S O}_{4}^{2-}$ & $\mathbf{C l}^{-}$ & $\mathbf{C a}^{2+}$ & $\mathbf{M g}^{2+}$ & $\mathbf{N a}^{+}+\mathbf{K}^{+}$ & $\begin{array}{c}\text { The sum } \\
\text { of ions }\end{array}$ \\
\hline $\begin{array}{l}\text { Western Bug- } \\
\text { Kamianka-Buzka (up- } \\
\text { per drain) }\end{array}$ & 58 & 59 & 98 & 76 & 66 & 87 & 60 & 66 \\
\hline $\begin{array}{l}\text { The Western Bug - the } \\
\text { conventional drain } \\
\text { "Border-3" } \\
\text { drain) }\end{array}$ & 23 & 25 & 38 & 33 & 27 & 37 & 25 & 28 \\
\hline
\end{tabular}

Table 10.Contribution of the Poltva to the biogenic runoff of the river Western Bug, calculated for two drains: 1) the Western Bug Kamianka-Buzka, below the confluence of the Poltva (upper); 2) the Western Bug is the conventional drain "Border-3", the closing drain in the Ukrainian part of the basin (lower), \%

\begin{tabular}{|l|c|c|c|c|c|c|}
\hline $\begin{array}{l}\text { Drain in the Western } \\
\text { Bug }\end{array}$ & $\mathbf{N H}_{\mathbf{4}^{+}}$ & $\mathbf{N O}_{\mathbf{2}}^{-}$ & $\mathbf{N O}_{\mathbf{3}}^{-}$ & $\mathbf{N}_{\text {total }}$ & min. & $\mathbf{S i}$ \\
\hline $\begin{array}{l}\text { Western Bug - } \\
\text { Kamianka-Buzka (Upper } \\
\text { drain) }\end{array}$ & 70 & 66 & 51 & 68 & 80 & 67 \\
\hline $\begin{array}{l}\text { The Western Bug is the } \\
\text { conventional border } \\
\text { "Border-3" (Lower drain) }\end{array}$ & 47 & 28 & 23 & 44 & 71 & 30 \\
\hline
\end{tabular}

As can be seen from Table. 9 ("Upper drain"), the share of the water runoff of the Poltva River at the place where it flows into in the Western Bug is 58\% of the water runoff of the main river. At the same time, the share of the total ion runoff of the Poltva River is higher - up to $66 \%$

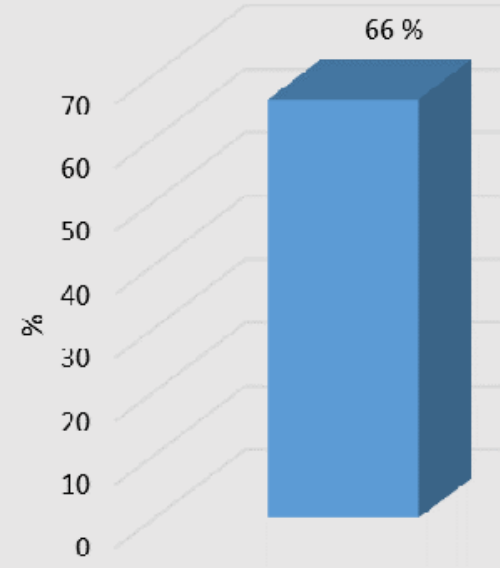

1
(Fig. 3). The share of the runoff of some main ions reaches: $76 \%\left(\mathrm{Cl}^{-}\right), 87 \%\left(\mathrm{Mg}^{2+}\right)$ and $98 \%\left(\mathrm{SO}_{4}{ }^{2-}\right)$. For total nitrogen, this figure equals $68 \%$, for phosphates - up to $80 \%$ (see Table 10).

Fig. 3.Contribution of the Poltva in the ionic runoff of the Western Bug, calculated for two drains:1) the Western Bug - Kamianka-Buzka, below the confluence of Poltva (upper); 2) the Western Bug - the conventional drain "Border-3", the closing drain the Ukrainian part of the basin (lower), \%

In the balance of runoff in the closing drain in the Ukrainian part of the Western Bug Basin ("lower drain" in Tables 9 and 10), the Poltva's influence is less evident. There, the share of the Poltva's water fun off decreases to $23 \%$. Although the share of the total ion runoff of the Poltava is 
still somewhat higher $-28 \%$, and the share of runoff of some main ions, anthropogenic impact indicators, reaches: $33 \%\left(\mathrm{Cl}^{-}\right), 37 \%\left(\mathrm{Mg}^{2+}\right)$ and $38 \%$ $\left(\mathrm{SO}_{4}{ }^{2-}\right)$. For total nitrogen, this indicator was $44 \%$, for phosphates - up to $71 \%$ (see Table 10).

Thus, the comparative methodological approach allowed determining a significant influence of the Poltva on the formation of the chemical composition of the Western Bug, especially in its upper part.

\section{Conclusions}

1. The hydrographic network of the Western Bug basin on the territory of Ukraine has 2,044 rivers.

2. The classification of the rivers of the Western Bug basin by catchment area, performed in accordance with the requirements of the EU WFD, showed the following results: in this basin within Ukraine there is one very large river, (actually this is the West Bug itself), and also three large rivers the Poltva, Rata and Luha. There are also 30 medium and 2,010 small rivers (among which 1,966 rivers are less than $10 \mathrm{~km}$ ).

3. The data obtained and the revealed regularities allowed us to determine the leading role of natural fac-tors in the formation of the hydrocarbonatecalcium ion composition of the river waters of the Western Bug basin. The content of the main ions and the salinity of the river waters are distinguished by a sufficiently clear seasonal character: a decrease in the spring flood and an increase in the low water level (mineralization of the water of the Western Bug - 497-573 mg/l).

4. Mineralization of the Poltva River (the left tributary of the Western Bug), located in the same natural conditions, is significantly different. So, in the area of the city of Lviv (the upper area of the Poltva River), it reaches $784-871 \mathrm{mg} / \mathrm{l}$, and at the mouth of the river (in the city of Busk, at the confluence of the Western Bug) 613-670 mg/l. In this case, the chemical type of water begins to affect sulfates and chlorides. This situation is explained by the discharge of sewage from the city of Lviv into the Poltva River.

5. At the same time, studies of the regime of nutrients, microelements, and specific pollutants in the water of the Western Bug did not find common regularities in their seasonal variations, which is related to the significant discreteness of the influence of anthropogenic factors on the formation of their concentrations.

6. The methodological approach used to calculate the flow of dissolved chemicals allowed us to estimate the balance of substances, both natural and anthropogenic, that are taken out with the waters of the Western Bug from the territory of Ukraine
$(93 \%)$, as well as from the territory of Poland (7\%) to the border with Belarus.

7. The comparative methodological approach allowed us to quantify the significant influence of the Poltva River on the formation of the chemical composition of the water of the Western Bug, especially in its upper part. The share of Poltva's water flow within the Western Bug is $58 \%$ of its water flow. At the same time, the share of the total ion flow is higher $-66 \%$. The share of the discharge of individual principal ions reaches: $76 \%\left(\mathrm{Cl}^{-}\right), 87 \%(\mathrm{Mg}$ $\left.{ }^{2+}\right)$ and $98 \%\left(\mathrm{SO}_{4}{ }^{2-}\right)$. For nitrogen, this figure is $68 \%$, for phosphates - up to $80 \%$.

\section{References}

Bug River Valley as the ecological corridor. State Threats - Protection, 2002. IUCN European Programme.

harakterystyka wod granicznego odcinkarzeki Bugwlatach 1990-1996. (1997) [Characteristics of the water of the border section of the Bug river in the years 1990-1996. (1997)]. Chelm: Biblioteka monitoringu srodowiska (in Polish).

Directive 2000/60/EC of the European Parliament and of the Councilof 23 October 2000 establishing a framework for Communityaction in the field of waterpolicy.Official Journal EU. L 327. 22/12/2000 P. 0001-0073. Retrieved from http://eur-lex.europa.eu/legalcontent/EN/TXT/?uri=CELEX:32000L0060.

Dzham O.A., Danilyuk I.V., 2017. Dinamika sostoyaniya kachestva poverhnostnyih vod baseyna $r$. Zapadnyiy Bug [Dynamics of the state of surface waters quality of the river basin Western Bug]. Vestnik Odesskogo gos. ekolog. un-ta. 21, 56-65 (in Russian).

Ertel A.-M. et al., 2012. Heavy loadand high potential: anthropogenic pressures and their impacts on the water quality along a lowland river (Western Bug, Ukraine). Environ Earth Sci. 65, 1459-1473.

Hagemann N., Blumensaat F., Tavares Wahren F. et al. (2014). The long road to improving the water quality of the Western BugRiver (Ukraine) - A multi-scale analysis. Journal of Hydrology. 519, 2436-2447. DOI: 10.1016/j.jhydrol.2014.01.013.

Karpuk V.K., 2015. Antropogennoe vliyanie na kachestvo rechnyih vod $\mathrm{v}$ basseyne Zapadnogo Buga. Institutsionalnyie osnovyi transgranichnogo predprinimatelstva [Anthropogenic impact on the quality of river water in the basin of the Western Bug. Institutional framework for cross-border entrepreneurship]. Byala-Podlyaska. Brest. 2, 71-76 (in Russian).

Khil'chevskii V.K., Chebot'ko K.A., 1994. Evaluation of the ecological and hydrochemical state of natural waters in Ukraine. Water Resources. 21(2), 166-172.

Khilchevskyi V. K., Hrebin V.V., 2017. Hidrohrafichne ta vodohospodarske raionuvannia terytorii Ukrainy, zetverdzhene u 2016 r. - realizetsiia polozhen 
VRD S [Hydrographic and water-management zoning of the territory of Ukraine, approved in 2016 - Implementation of the provisions of the EU WFD]. Hidrolohiia, hidrokhimiia i hidroekolohiia. 1(44), 8-20. (in Ukrainian).

Khilchevskyi V.K., Hrebin V.V., Zabokrytska M.R., 2016. Otsinka hidrohrafichnoi merezhi raionu richkovoho baseinu Visly (Zakhidnoho Buhu ta Sanu) na terytorii Ukrainy zghidno typolohii Vodnoi ramkovoi dyrektyvy YeS [Assessment of the hydrographic network of the Vistula river basin (Western Bug and San) in the territory of Ukraine according to the typology of the EU Water Framework Directive]. Hidrolohiia, hidrokhimiia i hidroekolohiia. 1(40), 29-41 (in Ukrainian).

Khilchevskyi V. ., Kurylo S. ., Sherstyuk N.P., 2018. Chemical composition of different types of natural waters in Ukraine. Journal of Geology, Geography and Geoecology. 27(1), 68-80.

Khilchevskyi V.K., Osadchyi V.I., Kurylo S.M. 2012. Osnovy hidrokhimii [Basics of hydrochemistry]. Nika-tsentr, Kiev (in Ukrainian).

Starodub G., Karabyn B., Ursulyak P., Pyroszok S., 2013. Assessment of anthropogenic changes natural hydrochemical pool Western Bug river. Studia regionalne i lokalne Polski poludniowowschodniej.Dzierdziówka - Kraków, T. XI. P. 79-90.

Tatukh S., Chalyi P., Mukha O., Mykhnovych A., 2012. Natural Conditions and Man-Made Influence upon Surface Waters Quality in the Western Bug River Basins. In: Transboundary Aquifers in the Eastern Borders of the European Union. NATO Science for Peace and Security Series C: Environmental Security. Springer, Dordrecht..Retrieved from https://doi.org/10.1007/978-94-007-3949-9_5.
Tokarchuk O.V., 2011. Monitoring kachestva poverhnostnyih vod transgranichnoy chasti basseyna reki Zapadnyiy Bug: sostoyanie i problemyi optimizatsii [Surface water quality monitoring of the transboundary part of the Western BugRiver basin: the state and problems of optimization]. Nauchnyie zapiski Brest.un-ta. 7. Ch. 2, 133-140 (in Russian).

Tränckner J., Helm B., Blumensaat F., Terekhanova T., 2012. Integrated Water Resources Management: Approach to Improve River Water Quality in the Western Bug River Basin. In: Transboundary Aquifers in the Eastern Borders of the European Union. NATO Science for Peace and Security Series C: Environmental Security. Springer, Dordrecht.Retrieved from https://doi.org/10.1007/978-94-007-3949-9_6.

Vodnyi kodeks Ukrainy, 1995 (z dopovnenniamy iz 2000 r.) [The Water Code of Ukraine, 1995 (with amendments from 2000 year] (in Ukrainian). Retrieved from http://zakon.rada.gov.ua/go/213/95вp.

Zabokrytska M.R., Khilchevskyi V.K., Manchenko A.P., 2006. Hidroekolohichnyi stan baseinu Zakhidnoho Buhu na terytorii Ukrainy [Hydroecological state of the basin of the Western Bug on the territory of Ukraine]. Nika-Tsentr, Kiev (in Ukrainian).

Zakhidno-Buzke baseinove upravlinnia vodnykh resursiv Derzhvodahentstva Ukrainy, 2017. Ofitsiinyi sait. [West-Bug water basin department of the State Agency of Water Supply of Ukraine. Official site]. Retrieved from http://zbbuvr.gov.ua. (in Ukrainian).

Zakrevskii D.V., Peleshenko V.I., Khil'chevskii V.K., 1988. Dissolved load of Ukrainian rivers. Water Resources. 15(6), 63-73. 